\title{
Euthanasia: a matter of life or death?
}

Sundaresh Menon ${ }^{1}$

\section{INTRODUCTION}

In a sense it all began here, in a bar in Singapore in 1995, when a young Englishwoman met a Cuban jazz musician, and despite her not being able to speak a word of Spanish and him not being able to utter a word of English, they fell in love. Debbie Purdy had already begun to experience early symptoms of Multiple Sclerosis when she met Omar Puente, but in the first flush of their relationship any thought of death and disease must have been the furthest thing from their minds. One would hope that they look back on their time in Singapore as a brief stop in paradise, given how much they have endured together since. They travelled through Asia for the next three years as Ms Purdy's health steadily deteriorated, gradually leaving her more dependent on her companion. When it was time for her to return to England, he followed. In the teeth of the odds, they have been together for the past 18 years, during which time she has become the most prominent face of the assisted-dying debate in the UK, and the subject of what is perhaps the most important decision of the House of Lords bearing on the extent of the individual's right to control the circumstances of her death. Theirs is both a legal saga and a love story, and it serves to remind us that - whatever our political, religious or moral leanings - the assisted dying debate remains an irreducibly human issue. It follows that we must summon all the compassion and kindness in our hearts when broaching this matter.

\section{DEFINITIONS}

The subject of assisted dying is an intensely complicated one. There are many facets to it with very few ready answers. It would therefore be helpful to begin with some conceptual distinctions and definitions. The most common abstraction used to represent the core principle in the debate on assisted dying has been the "right to die". This is a compendious concept which encapsulates the competing notions of "sanctity of life" on the one hand and "freedom of choice" on the other. Curiously, it suggests that we are at liberty to die, just as we are at liberty to live. However, as with any conversation of such moral complexity we must be wary of reductive labels. Taken literally, the "right to die" is a misnomer - we are all obliged to die. Death is the one thing in life that is utterly inevitable and irresistible. It is the most fundamental and universal of obligations. The involvement of legal rights arises only in relation to accelerating death, and more specifically in choosing the point of death. It is, as perhaps only a lawyer would say, a question of whether there is an option for the early termination of our lease on life.

The manner of such termination is also of legal significance. Death can be induced by either an act or an omission. The common law has long recognised that a person has the right to refuse treatment on the basis that forcing him to suffer such treatment would entail an impermissible invasion of his bodily integrity. This right of refusal is a time-honoured cornerstone of personal autonomy. It has even been extended to situations where a patient is unable to express his wish to refuse treatment by recasting it as a question of whether the continuation of previously unsolicited invasive treatment is ultimately in the best interest of a patient who is in a persistent vegetative state ("PVS") and hence unable to form or articulate his will. ${ }^{2}$

However, the common law has historically declined to recognise that autonomy extends to a right to take life itself into one's own hands. Indeed, the infliction of fatal harm to oneself has always been seen as a profound abdication of bodily integrity.

Viewing the act-omission distinction from the perspective of a medical practitioner, there is a readily discernible difference between "killing" and "letting die". This is also often translated into a distinction between "active" and "passive" euthanasia. ${ }^{3}$ But the ethical boundaries are perhaps less intuitively delineated where medical decisions made in the interests of the patient have the secondary effect rather than the primary intent of hastening their demise. The doctor who withdraws a feeding tube is taking positive action but we do not take him to be "killing" the patient. The Aquinian notion of "double effect" is an important doctrine which seeks to distinguish between the permissible and impermissible consequences of any such action on the basis of the actor's intentions. ${ }^{4}$ This is also encapsulated within s 88 of our Penal Code (Cap 224, 2008 Rev Ed) ("Penal Code"), which provides that it is not an offence to commit an act which harms a person so long as it was not intended to cause death, was done with the consent of the person harmed, in good faith, and for the benefit of that person. Thus a drug administered to relieve a patient from acute pain and discomfort might carry with it a risk that it might hasten his demise; but this is treated

\footnotetext{
${ }_{1}$ I would like to acknowledge the assistance of my law clerk, Jonathan Yap, who assisted me in researching and preparing this paper and who discussed these ideas with me.

${ }^{2}$ Airedale NHS Trust v Bland [1993] 1 AC 789 at 859 per Lord Keith of Kinkel and at 884 per Lord Browne-Wilkinson

${ }^{3}$ For a challenge to this distinction see J. Rachels, "Active and Passive Euthanasia," The New England Journal of Medicine 292 (January 9, 1975) pp78-80

${ }^{4}$ Summa Theologiae II-II Qu. 64, Art.7
} 
as fundamentally different from administering the same drug for the purpose of hastening the end of his life even if this brings incidental relief from suffering.

This leads us to an important set of definitions related to the various modes by which accelerated dying can be effected. Euthanasia entails the termination of the life of a patient by someone other than the patient himself. A working definition of euthanasia as it is commonly understood is:

An action that results in the immediate merciful killing by a doctor of a sick and suffering patient who has consented to this action. It is the deliberate and very humane ending of a patient's life to prevent further suffering ... and rests on two fundamental principles: autonomy and mercy. ${ }^{5}$

Voluntary euthanasia takes place at the patient's request but it is the physician who executes the final act. This is to be distinguished from assisted suicide, where the patient performs the final act and causes his or her own death. The assistance may come in the form of practical assistance, such as that rendered by friends and family members to those who travel abroad for the purpose of ending their lives. It may also take the form of medical assistance.

Physician assisted suicide is presently legal in the Netherlands, Luxembourg, Belgium, Switzerland and the states of Washington, Oregon and Montana in the US. It is most prominently associated with the Dignitas clinic in Zurich, which was founded in 1998 with the avowed aim of assisting those with "medically diagnosed hopeless or incurable illness, unbearable pain or unendurable disabilities" to end their lives with dignity. The protocol for physician assisted suicide in Dignitas usually involves an oral dose of an antiemetic drug, followed by a lethal overdose of barbiturate dissolved in a glass of water. The patient will become drowsy and fall asleep before dying of respiratory arrest about 30 minutes later. ${ }^{6}$ Crucially, the drugs are all consumed by the patient rather than administered by a physician.

The focus of my lecture today will be on accelerated dying and the practices of assisted suicide and voluntary euthanasia, which will be collectively referred to as assisted dying. ${ }^{7}$

\section{CONCEPTUAL CHALLENGES}

Our survey of the conceptual distinctions and definitions has taken us from the well-established right to refuse treatment to the contested right to accelerate death and on to the controversial means by which the latter may be actuated. In the process of doing so the centre of gravity has started to shift, albeit somewhat imperceptibly, from our personal responsibility for ourselves to our collective responsibility for others. If we begin from the premise of a competent individual's liberty to choose what treatment he receives, something that is rooted in the notions of personal autonomy and bodily integrity, we will inevitably have to consider what should be done at the other end of the spectrum, where he is unable to formulate or communicate his choice. It becomes apparent that the lodestar of individual autonomy can only take us so far. Where contemporaneous self-determination is impossible, we are forced to look to other bearings to guide us through the difficult task of substituting the decision-maker. There are no straight-forward answers.

One existing solution would be to rely on Advance Medical Directives ("AMDs") or Living Wills which are direct expressions of personal choice, albeit usually at a remote point in time while the patient was still competent and able. Under s 3(1) the AMD Act (Cap 4A, 1997 Rev Ed), any person who has attained the age of 21 and who desires not to be subjected to extraordinary life-sustaining treatment in the event of his suffering from a terminal illness, may at any time make an AMD in the prescribed form. However, even such directives cannot simplistically be taken as conclusive of the patient's present preferences as opposed to what was in his mind at the time of making the directive. This is all the more so if a long time has elapsed between the creation of the directive and the point of treatment, within which one must recognise the considerable prospect of changed perspectives brought about by a lifetime of experiences, including that of the illness itself.

The complexity which is inherent even where AMDs and Living Wills have been prepared has been helpfully illustrated by Richard Posner's multiple-selves analysis. ${ }^{8}$ The underlying idea is that each individual could be taken as a "locus of competing selves" instead of a monolithic entity across time. Our existential preferences at the point of treatment might therefore be greatly different from those of our younger selves. If so, an advance directive can become a means by which the destructive designs of one's younger self are inflicted upon one's older self. Whilst we would not want to take this analysis too far, it at least offers a mental model by which we can test our intuitions as to whether AMDs offer a fail-safe means of ascertaining the present intentions of the patient.

Where the patient cannot indicate his preference, let alone exercise his will, it is inevitable that some kind of substituted

\footnotetext{
${ }^{5}$ Howard Ball, At Liberty To Die: The Battle for Death with Dignity in America (NYU Press, 2012) ("At Liberty To Die") at p69. See also the Final Report of the Commission on Assisted Dying (Demos, 2011) (“RCAD”) at p37

${ }^{6}$ http://www.dignitas.ch/index.php?option=com_content\&view=article\&id=22\&ltemid=5\&lang=en (accessed on 8 March 2013)

${ }^{7}$ RCAD, supra $\mathrm{n} 5$ at $\mathrm{p} 37$

${ }^{8}$ Richard A Posner, "Euthanasia and Health Care: Two Essays on the Policy Dilemmas of Aging and Old Age" The Tanner Lectures on Human Values, 10 and 11 October 1994 at pp27-38
} 
decision-maker will have to be relied upon, even if it is that same patient's younger self. In such a situation, the law is not so much acceding to the patient's intentions as it is maximising patient autonomy by seeking the next best thing to a truly personal election. Ultimately this is an arena in which neither law nor medicine can yield perfect solutions.

The ethical difficulties of course become even more acute where there is an absence of any evidence of the patient's preferences regarding life-sustaining medical treatment not even those of a much younger self of that patient. In these cases an external substitute decision-maker - whether this is an individual such as the patient's next-of-kin, a corporate body such as a medical board, or even an institution like the court - will have to make a proxy decision of the most personal order for the patient. What considerations should be factored into the calculus of such a decision? Should it be centred on a view of what the patient would have intended had he been in a position to form a conclusion, or on a view of what would be in his best interests? Neither approach is without its drawbacks.

In the former case, the theory is that it is permissible to reach a conclusion by reference to preferences that are to be inferred from what is known about the patient even if it is when he was healthier. But as noted by Posner's multiple-selves analysis, it is already difficult to surmise the extent to which even the patient's expressed preferences remain intact at the moment it is no longer a theory but something to be acted upon in a final and irrevocable way. How much more difficult would it be to deduce this as a matter of inference? One might also question whether these preferences are better deduced by reference to who they were when they were healthier? Are we in fact letting the decision be made by reference to the decision maker's own theoretical preferences of what he imagines he would wish for himself if he were to find himself in this unimaginable situation? We can test our intuitions to the breaking point when we look at mentally ill patients who never expressed any preferences at all. If we accept that a substitute decision-maker can act on behalf of such a patient, we raise the spectre of involuntary euthanasia.

On the other hand, if we shift the emphasis towards an objective assessment of the patient's best interests we might place the lives of the most vulnerable groups in society at risk. How are those interests to be determined? How negotiable would be the patient's interest in staying alive? Are a patient's best interests affected by how willing his nearest and dearest are to invest the enormous time, energy and effort required to continue to provide care?
Any decision made, using whichever approach, would necessarily be permeated with assumptions as to deeply subjective matters such as the meaning of death, the value and quality of one's existence, what constitutes a person's identity, and how existential choices are made.

I outline these conceptual challenges so as to illustrate how quickly we will wander into a maze of intractable questions once we set off on a train of enquiry directed at deciding for the patient whether to continue treatment. The process of dying is becoming ever more institutionalised and therefore ever more complicated. The questions posed are not susceptible to neat solutions or easy answers and the underlying differences are ultimately ideological rather than analytical in nature. We have yet to find the philosophical tools to cut through the Gordian Knot, but I hope to unravel, at least to some degree, three thematic strands. These will touch on the nature of rights, the interaction between law and science, and the potential implications for policy.

\section{UNIVERSALISING HUMAN RIGHTS}

Much of the discourse on this subject is rooted in the language of rights. As we shall see, the right to decide whether to take steps to accelerate death is couched as an integral part of the right to life and to live on one's own terms. Rights are legal constructs. But they do not exist in metaphysical ether or in the mind of man alone; instead, rights are complicated molecular structures ${ }^{9}$ contained within systems of law which prescribe rules ${ }^{10}$ on the creation, application, and enforcement of these structures. As Jeremy Bentham wrote in The Anarchical Fallacies - "Right, the substantive right, is the child of law: from real laws come real rights". ${ }^{11}$ In other words, the reality of a right cannot be separated from its realisation. Thus, while we may argue that at a high level of abstraction human rights are universal, the expression of such rights as a matter of concrete application must be national. I do not mean to suggest that broad consensus on certain truths of the human condition are of no value. On the contrary, they can be tremendously important.

The American legal scholar Cass Sunstein has described such consensus as "incompletely theorised agreements", in the sense that they are not fully specified or worked through and may thereby co-exist with deep disagreement on particular issues even between those who are in strong and emphatic agreement on general principles. Sunstein has also observed that:

Incompletely specified agreements have distinctive social uses. They may permit acceptance of a general aspiration when people are unclear about what the aspiration means, and in this sense they can maintain a measure of both

\footnotetext{
${ }_{9}^{9}$ Wesley Hohfeld, Fundamental Legal Conceptions as Applied in Judicial Reasoning and Other Legal Essays, 23 Yale L.J. 16, pp28-59 (1913)

${ }^{10}$ HLA Hart, The Concept of Law (Oxford University Press, 2012) pp79-99

11 In The Works of Jeremy Bentham, vol 2 (William Tait, 1843) p523
} 
stability and flexibility over time. At the same time, they can conceal the fact of large-scale social disagreement about particular cases. ${ }^{12}$

This is not just a matter of abstract theory but is reflective of the simple fact that people can agree on broad propositions at a certain level of abstraction which can give way to quite deep divisions when the abstraction begins to concretise.

As such, even though we must reserve a place in our collective consciousness for universal truths and values, we must also remember that until they find expression in our own system of law they are both unrealised and incomplete. One of the great recent thinkers of the common law, the retired English Judge Leonard Hoffmann, who had been a Lord of Appeal in Ordinary, made the same point in characteristically forceful terms in relation to the United States' Bill of Rights, saying:

The important lesson which one draws from the American experience... is that, at the level of abstraction, human rights may be universal. ... At the level of application, however, the messy detail of concrete problems, the human rights which these abstractions have generated are national. Their application requires trade-offs and compromises, exercises of judgment which can be made only in the context of a given society and its legal system".13

This is an especially important point to keep in mind in relation to the subject of assisted and accelerated dying. We must arrive at our conclusion on the strength of our own convictions, values and experiences, instead of imbibing those of another polity. There has been a knee-jerk tendency to look to other jurisdictions which have legalised assisted dying, and to say that this is evidence of how a progressive and regulated framework can be implemented without rupturing the social fabric. At root this is to pose the simple question, "if they can do it, why can't we?"

A cogent response to this question must begin with the acknowledgement that the reforms in countries such as the Netherlands and Belgium have been born of their own sociopolitical conditions. The end-state in these jurisdictions have been reached via a tortuous process which reflects a wider social struggle to come to terms with accelerated and assisted dying. In the Netherlands, for example, the legal process began in the Dutch Supreme Court, which held in 1984 that a physician who ends the life of a patient may invoke the defence of necessity. ${ }^{14}$ This was a watershed development which provoked a long-running debate both within the courts and Dutch society at large. It materialised as a prosecutorial discretion not to bring charges against doctors who took, or assisted in the taking of, a patient's life at their request even though both voluntary euthanasia and assisted suicide remained offences under Articles 293 and 294 of the Dutch Penal Code.

It was not until 2002, some two decades after the Dutch Supreme Court's decision, that formal legislative codification was achieved. The Termination of Life on Request and Assisted Suicide (Review Procedures) Act ("the Dutch Act") sets out the due care criteria for a physician who terminates a patient's life on request or assists in that patient's suicide. ${ }^{15}$ Articles 293 and 294 of the Dutch Penal Code have been amended to carve out exceptions for cases where the due care criteria have been complied with, yet they remain on the statute books. This means that assisted dying is still nominally an offence in the Netherlands, even though certain practices have been legalised. Simply saying that "assisted dying is legal in the Netherlands" does not fully capture the nuances of the Dutch position; but more importantly, it fails to capture how the present Dutch position is a product of protracted public debate and soul-searching on the part of the Dutch people.

Of course, the features of existing regimes can be culled to provide the nuts and bolts of our own regulatory system for assisted dying ${ }^{16}$ but we should not place the cart before the horse. Even if we can reach broad agreement on the value of being given the option to choose the point of one's death, we must still have a serious conversation about whether and how this is to be realised in practice. This is an intensely important choice about intensely important issues, and it affects not only personal rights but also collective ones. For any decision to be legitimate it will have to be speak to our national character as much as to abstract ideals.

I might refer here to a point made last December by Chris Grayling the Lord Chancellor of the United Kingdom in commenting on the growing scale of the work of the European Court of Human Rights. ${ }^{17}$ Grayling traced the original impetus behind the European Convention on Human Rights, namely the "brutality of parts of Europe in the Thirties and Forties" including the excesses of the Stalinist Gulags, before making this important observation:

Over more than half a century, the European Court of Human Rights in Strasbourg has moved further and further away from the intention of those politicians who shaped

\footnotetext{
12 Cass Sunstein, “Incompletely Theorized Agreements”, 108 Har. L. Rev. 1733, pp1739-40

${ }^{13}$ Lord Hoffmann, "The Universality of Human Rights" Judicial Studies Board Annual Lecture, 19 March 2009 at [15]

14 Schoonheim, Netherlands Jurisprudentie 1985, no 106

15 John Griffiths et al, Euthanasia and Law in the Netherlands (Amsterdam University Press, 1998) at pp62-63

${ }^{16}$ Stanley Yeo \& Toh Puay San, "Decriminalising Physician-assisted Suicide in Singapore" [2010] SAcLJ 379 at pp395-396

17 Chris Grayling, "Let us concentrate on real human rights: The European Court has drifted too far from its principles - and we want to put that right", The Daily Telegraph 18 December 2012
} 
the original convention. It has pried more and more into matters that should be routine issues for national courts and parliaments to deal with.

Grayling's emphasis on national courts and parliaments dealing with national issues underscores this notion that there is a limit to the universalism of discourses about rights, and especially so one that is so potentially intractable as that concerning assisted dying.

\section{RECOGNISING SCIENTIFIC LIMITS}

Law is the expression of society's choices about the policy choices we will live by and if society chooses to recognise the right to get assistance in dying, that will be reflected in the law. But when prospective policies interface with science, we must be sensitive to the fact that there remains a gap between what we know, what we know we don't know, and in the words of Donald Rumsfeld, ${ }^{18}$ what we don't know about what we don't know.

This point is illustrated by the recent case of Hassan Rasouli in Canada. Mr Rasouli was diagnosed as being in a PVS after contracting bacterial meningitis and falling into a coma. His doctors were of the view that he had no reasonable chance of regaining consciousness. They recommended that his feeding tube and ventilator be removed. This led to a legal battle between Mr Rasouli's doctors and his devoutly Islamic family as to who should have the final power to decide his medical fate. The Rasoulis prevailed at first instance and on appeal. The doctors then took their case to the Supreme Court of Canada, which heard the matter in December 2012. By April 2012, however, Mr Rasouli had started to show signs of improvement. His family claimed that he was able to blink in response to words and could give a weak thumbs up. His neurological condition was reviewed and upgraded from PVS to "minimally conscious". As we await the decision of the Canadian Supreme Court, it strikes me that - whatever the outcome - this is a case which highlights the tension between scientific opinion and religious faith, as well as the difficult interaction between law and medicine, when they come to a head on end-of-life issues.

The decision to accelerate death is irreversible, and we may find out too late that it was made on the basis of erroneous assumptions - particularly as the full extent of brain damage might not be ascertainable whilst the patient is alive. There remains a lot which is not known about whether recorded mental activity or observable physiological responses can or cannot be equated to consciousness; about the possibility of cognitive recovery; and even about the likelihood of death. One of the landmark cases on accelerated dying in the US involved Karen Ann Quinlan, a 21-year-old woman who slipped into a coma after arriving home from a party. She suffered irreversible brain damage after experiencing an extended period of respiratory failure. The Quinlan family sought a court order for the patient's respirator to be removed, and the New Jersey Supreme Court ruled in their favour. It was thought that she would die once the respirator was removed but Karen Ann Quinlan surprised everyone by continuing to breathe unaided. She lived on in a PVS until her death almost a decade later.

Closer to home, and even more dramatic, some among you may have heard the story of Suzanne Chin, a Singaporean lawyer who was working in Hong Kong at the time (and who is the sister of your colleague Dr Alan Chin who also has the details of her medical history and who kindly reviewed and confirmed the accuracy of what I am about to state). Suzanne today is alive and thankfully in perfect health but on 20 April 2009, she was warded in the intensive care unit of a hospital in Hong Kong after she suffered a cardiac arrest. When she was brought to the hospital on that Monday morning at $8.38 \mathrm{am}$, she was unconscious with unrecordable blood pressure. Resuscitation efforts followed and these lasted for 2 hours. She was intubated and administered dopamine and adrenaline intravenously. Although she was eventually resuscitated, her prognosis was poor. Her doctors diagnosed an acute aortic valve prolapse leading to cardiac arrest. They also informed the family that she had brain stem death. Suzanne's husband was advised to consider authorising the doctors to switch off her ventilator since for all practical purposes, she was dead and there was no hope of recovery.

The family requested a second opinion from a neurologist who examined her. He observed that her pupils were fixed and dilated. There was no gag and cough reflex; no pain reflex, no vestibulo-ocular reflexes; no response to deep pressure applied to various parts of her body. She was flaccid and a-reflexic. The neurologist also diagnosed brain stem death. On both 20 and 21 April 2009, Suzanne met three of the four criteria associated with total brain death: ${ }^{19}$ she was in an unresponsive coma; she was unable to breathe spontaneously; and there was an absence of any brain stem reflexes. As to the fourth criteria, the absence of electrical activity of the brain, when she was tested for this for the first time towards the end of the second day, 21 April 2009, some activity compatible with massive gross encephalopathy, signifying severe brain damage, was detected. Twenty-four hours later, she started to respond to stimuli. Eight days after her initial admission to hospital, she was discharged. Today, she is back in Singapore leading a normal life and showing no signs of any damage at all.

I mention these cases to make the point that there are limits to what we know and what science can tell us. In many of the

\footnotetext{
${ }^{18}$ Transcript of the Department of Defence News Briefing, February 122002

${ }^{19}$ At Liberty To Die, supra $\mathrm{n} 5$ at $\mathrm{p} 14$
} 
cases that have come to the courts, judges are invited to make binary decisions on matters of life-and-death based on scientific predictions framed in percentages when what eventually emerges as fact can wholly defy the odds. Where the choice is between the irreversible and the remotely possible, it would seem reasonable to favour caution and prolong life.

\section{THE “SLIPPERY SLOPE”}

Let me turn to the third of the conceptual strands concerning the development of society's response to this issue - what is referred to by some as the danger of the slippery slope. As I pointed out earlier in this lecture, the subject matter of assisted and accelerated dying raises an inevitable procession of conceptual challenges. We have already seen how acceptance of a substitute decision-maker shifts us away from the notion of personal autonomy and closer to, if not actually over, the margin between voluntary and involuntary euthanasia. There is also a thread which could be traced from advance directives to assisted suicide for the terminal ill, and on to voluntary euthanasia for otherwise healthy individuals who have simply lost the will to live, even perhaps only temporarily. This has been the evolution of the position on assisted dying in the Netherlands. The public debate began as a campaign for terminally ill patients to receive medical assistance to end their lives with dignity. In the watershed Schoonheim case $^{20}$ a General Practitioner had performed euthanasia on a 95-year-old patient who was bedridden but not suffering from any terminal illness. The Dutch Supreme Court found that the defence of necessity was applicable, and subsequent cases have further delineated the terms and limitations of that defence. The Dutch Act does not limit euthanasia to persons with terminal illnesses. Instead, the yardstick used is that of "suffering", which includes both mental and physical suffering. Patients who are suffering from depression will therefore be permitted to undergo or subject themselves to euthanasia. In 2006, the Royal Dutch Medical Association concluded after a three year inquiry that "being over the age of 70 and tired of living" should be accepted as one of the reasons for euthanasia ${ }^{21}$ though it has to be said that the position continues to evolve and develop. ${ }^{22}$

It was also reported late last year that Belgium is considering a significant change to its euthanasia law which would allow minors and Alzheimer's patients to undergo the procedure. ${ }^{23}$ We are in no position to pass judgment on the Dutch or Belgian experience with assisted dying, and what to some is a "slippery slope", others might see as the march of progress. However,
I think it is important to acknowledge at the outset that this is an area of law where there will be a constant impetus for further liberalisation because it is a fundamentally ideological matter.

The schisms within the subject of accelerated and assisted dying are so wide that public opinion, and therefore public policy, will not easily find a point of natural equilibrium. The noted philosopher, Joseph Raz, recently argued that access to voluntary euthanasia cannot cogently be conceived as a narrow right, since it must be based on the general value of being able to choose the time and manner of one's death. ${ }^{24}$ Raz's opinion is that this will inexorably be accompanied by changes in culture and attitudes.

The concern with the inability to steer a course that averts the danger of the slippery slope caused Justice David Souter of the United States Supreme Court in Washington v Glucksberg ${ }^{25}$ to vote with the majority and hold that a statute that prohibited physician assisted suicide was not unconstitutional. A brief extract from Justice Souter's judgment bears quoting:

... Voluntary and involuntary euthanasia may result once doctors are authorized to prescribe lethal medication ... for they might find it pointless to distinguish between patients who administer their own fatal drugs and those who wish not to, and their compassion for those who suffer may obscure the distinction between those who ask for death and those who may be unable to request it. The argument is that a progression would occur, obscuring the line between the ill and the dying, and between the responsible and the unduly influenced, until ultimately doctors and perhaps others would abuse a limited freedom to aid suicides by yielding to the impulse to end another's suffering under conditions going beyond the narrow limits the respondents propose. ...

... [O]ne of the points of restricting any right of assistance to physicians, would be to condition the right on an exercise of judgment by someone qualified to assess the patient's responsible capacity and detect the influence of those outside the medical relationship.

The State, however, goes further, to argue that dependence on the vigilance of physicians will not be enough. First, the lines proposed here (particularly the requirement of a knowing and voluntary decision by the patient) would be more difficult to draw than the lines that have limited other recently recognized due process rights. ... Second, this difficulty could

${ }^{20}$ See $n 14$

21 http://www.ncbi.nlm.nih.gov/pmc/articles/PMC543860/ (accessed on 8 March 2013); see also J Pereira, "Legalizing euthanasia or assisted suicide: the illusion of safeguards and controls"("Pereira”) Curr Oncol. 2011 April Vol 18(2) e38-e45

22 KNMG, Position Paper: The Role of the physician in the voluntary termination of life (2011) (Chairman: Prof AC Nieuwenhuijzen Kruseman)

${ }^{23}$ http://www.france24.com/en/20121218-belgium-looks-euthanasia-minors-alzheimers-sufferers (accessed on 8 March 2013)

24 Joseph Raz, "Death in Our Life", delivered at the Annual Lecture of the Society for Applied Philosophy (electronic copy available at: http://ssrn.com/abstract=2069357)

${ }^{25} 521$ US 702 
become the greater by combining with another fact within the realm of plausibility, that physicians simply would not be assiduous to preserve the line. They have compassion, and those who would be willing to assist in suicide at all might be the most susceptible to the wishes of a patient, whether the patient were technically quite responsible or not. Physicians, and their hospitals, have their own financial incentives, too, in this new age of managed care. Whether acting from compassion or under some other influence, a physician who would provide a drug for a patient to administer might well go the further step of administering the drug himself; so, the barrier between assisted suicide and euthanasia could become porous, and the line between voluntary and involuntary euthanasia as well. The case for slippery slope is fairly made out here, ... because there is a plausible case that the right claimed would not be readily containable by reference to facts about the mind that are matters of difficult judgment, or by gatekeepers who are subject to temptation, noble or not.

These concerns are not to be dismissed as patently fanciful. One study suggests that whereas legal restrictions and safeguards have been enacted wherever euthanasia or assisted suicide has been legalised, these have been "regularly ignored and transgressed" often without prosecution. ${ }^{26}$ The same writer suggests that the acceptance of these transgressions creates a social slippery slope with the practice gradually expanding, both in terms of what procedures will be acceptable as well as in diluting the qualifying criteria so that it may no longer even be necessary to demonstrate terminal illness. If this is the reality then the debate needs to be evaluated from the vantage point of the end game where suicide is freely and fully accepted as a legitimate exercise of personal autonomy; where there are no effective or meaningful restrictions on who qualifies or on the rendering of assistance; and where the fate of those unable to articulate their choice is left in the hands of others.

Last December an article appeared in the Irish Times entitled "Introducing assisted suicide 'entirely radical'". ${ }^{27}$ The report carried a summary of the testimony of Dr Tony O'Brien and Prof Rob George in the ongoing case involving Marie Fleming who was challenging the constitutionality of Ireland's ban on assisted suicide. Dr O'Brien argued that the existence of the ban made the position clear for doctors. He expressed the fear that if the ban were no longer in place it could result in vulnerable people choosing to end their lives so as not to burden others. Dr O'Brien thought that the real answer to Ms Fleming's circumstances was to be found in beneficial palliative care. Prof George, a palliative care specialist, contended that if assistance in suicide were allowed, it would reclassify the role of medicine, and result in seeing the intentional ending of one's life as a societally mandated good.

The report also contained this sentence:

In the UK, among the most vocal opponents of assisted suicide were disability groups, who believe it involves making assumptions about their quality of life, capacity and value when they are already at the receiving end of assumptions concerning their disabilities.

Without examining the empirical evidence to substantiate the last point, it seems legitimate to conclude that if recourse to assisted suicide or euthanasia was, for argument's sake, permitted, but only for those above 70, or those with Alzheimer's or dementia or even depression or those with terminal illnesses, and not others, then an impression is given that society has no (or at least low) collective interest in fighting to preserve the lives of those in these groups. Put another way - if assisted suicide is not available to a 65-year-old, but is available to a similarly situated 70-year-old, what does that say about our attitude towards aging and the value of living past 70 ?

In this regard, reference may be made to the impassioned speech of Baroness Campbell of Surbiton, who is disabled herself with the degenerative condition of spinal muscular atrophy, and a noted campaigner for disabled people's rights. Speaking at the debate in the UK House of Lords concerning the introduction of legislation on assisted suicide, she said: ${ }^{28}$

... if these amendments were to succeed, despair would be endorsed as a reasonable expectation for which early state-sanctioned death is an effective remedy. Is this really the message that we wish to give disabled and terminally ill people? Is this really the future that we wish to offer those who become terminally ill? Those of us who know what it is to live with a terminal condition are fearful that the tide has already turned against us. If I should ever seek death - there have been times when my progressive condition challenges me - I want a guarantee that you are there supporting my continued life and its value. The last thing that I want is for you to give up on me, especially when I need you most. I urge your Lordships to reassure us by rejecting this amendment.

Hers is a particularly eloquent voice. In 2006, Baroness Campbell covened the group "Not Dead Yet UK" and on its website in a section on assisted suicide, it says: ${ }^{29}$

Disability concerns are focused on the systemic implications of adding assisted suicide to the list of "medical treatment options" available to seriously ill and disabled people.

\footnotetext{
${ }^{26}$ Pereira, supra $\mathrm{n} 21$

27 The Irish Times, 13 December 2012

${ }^{28}$ HL Deb 7 July 2009 c 614

${ }^{29}$ http://www.notdeadyet.org/assisted-suicide.talking-points (accessed 6 March 2013)
} 
And a little further on the same page:

In a society that prizes physical ability and stigmatizes impairments, it's no surprise that previously able-bodied people may tend to equate disability with loss of dignity. This reflects the prevalent but insulting societal judgment that people who deal with incontinence and other losses in bodily function are lacking dignity. People with disabilities are concerned that these psycho-social disability-related factors have become widely accepted as sufficient justification for assisted suicide.

And in a note entitled "Stop trying to kill us off" published in The Guardian, 9 May 2006, Baroness Campbell had this to say: Assisted dying is not a simple question of increasing choice for those of us who live our lives close to death. It raises deep concerns about how we are viewed by society and by ourselves. I have a severe form of spinal muscular atrophy, and require 24-hour assistance. Many people who do not know me believe I would be "better off dead". Even more argue: "I couldn't live like that." And some suggest that advances in genetic screening should be used to enable parents to choose whether to have a child with disabilities.

Assisted Dying for the Terminally III, Lord Joffe's private member's bill ... has the backing of the Voluntary Euthanasia Society (recently renamed Dignity in Dying), and according to their polls, the support of the British public.

Yet it has failed to get the endorsement of a single organisation of disabled people. Three major national charities have condemned it, and leading campaigners have united under the banner of Not Dead Yet UK to make the voice of disabled people heard. The very people the bill is intended to help, the terminally ill and disabled, are frightened by what it seeks to achieve.

$\cdots$

Legalising premature death as a treatment option will place pressures on people near the end of their lives. It will be the cheapest, quickest and simplest option - all more attractive to health and social care services than developing and providing expensive, and potentially long-term, services. The relationship between care givers and receivers will be irrevocably damaged.

The sentiment that unites these various statements is the anxiety that indeed there is a steep slippery slope downwards; that indeed social attitudes will change about issues such as life and death, or disability; and eventually impact the choices we make about how to allocate scarce economic resources.
If we return here to the difficulties that have been traced with entrusting end-of-life decisions to substitute decision-makers, these get greatly exacerbated when the range of possible ailments causes us to conflate biological death with a different type of "death" where it is the personality that is no longer recognisable. Will there no longer be a distinction between the conventionally dead person, the patient in a PVS and the one suffering from advanced dementia or Alzheimer's?

There are at least two potential concerns with setting some limit on those who can seek assistance in suicide by reference to how advanced their illness is. First, as has been observed, there is the danger that this will be the thin end of the wedge and may transform our attitudes and obscure the line between the ill and the dying. But second, it is also somewhat counterintuitive. In the course of the oral arguments in Washington v Glucksberg, Justice Antonin Scalia observed: ${ }^{30}$

I hate to tell you, but the dying process of all of us has begun and is underway. It's just a matter of time. And it seems to me that the patient who has ten years of agony to look forward to has a more appealing case than the patient who is at the threshold of death.

One of the problems with the slippery slope is that what seems unthinkable today may not be so tomorrow. It could be said that the abolition of slavery was once unthinkable; or that universal adult suffrage was once unthinkable. Plainly, the fact that something is unthinkable cannot be a reason for not changing or moving in a progressive way. But the debate about assisted suicide is perhaps different because it has the potential to affect our values and ideas about life itself.

In the final analysis, there are perhaps four points that underlie the concern with the slippery slope. The first is that whereas there is something of a clear, bright line in the act-omission divide of the common law, once that is lost and the notion is accepted that a liberty right exists which permits positive acts being taken to hasten death or end life, it may be difficult to find an alternative stopping-point that is coherent and sensible. Secondly, attempts to restrict access to any such right may be questionable as a matter of logic and intuition. Thirdly, in seeking to understand and explain any restriction that might be imposed on those who may avail themselves of such a right and the circumstances under which they may do so, we might be saying something about our collective interest in seeking to preserve their lives, even if subconsciously at first. And fourthly, the inclusion of active steps to terminate life as a medical treatment option might fundamentally alter the role of doctors and the nature of their relationship with patients. Given this, if answers are to be found, they should perhaps be looked for in the context of an honest and open appraisal of just where

${ }^{30}$ Quoted in At Liberty To Die, supra n 5 at p 92 
it might all end. Is the late Dr Jack Kevorkian's approach to these issues one we can live with? In his book Prescription Medicine The Goodness of Planned Death, he observed: ${ }^{31}$

It's time for a society obsessed with planned birth to consider diverting some of its attention and energy from an overriding concern with longevity of life at all costs to the snowballing need for a rational stance on planned death, i.e. the purposeful ending of human life by direct human action.

\section{THE PRESENT STATE OF THE LAW INTERNATIONALLY}

With these broad themes in mind I would like to take a look at the state of the law on accelerated and assisted dying across a range of jurisdictions. We have already touched on the position in the Netherlands and Belgium. It is interesting that to date almost all countries in which some form of assisted dying is practiced or has been practiced operate on a civil law system. ${ }^{32}$ Civil law systems date back to the Roman law, and are primarily distinguished by a central code in which all legal rules are embodied. Unlike in common law systems such as ours, courts in civil law systems are not bound by previous decisions. Judges also play a more inquisitorial than adjudicatory role. This has affected the ability of courts to deal with these issues not only in the Netherlands but also in Japan and Columbia.

The Japanese position on euthanasia is almost entirely derived from local district court decisions which together set out a framework for the legality of "death with dignity". ${ }^{33}$ The state of the law is more definitive in Columbia, where euthanasia was decriminalised by a ruling of the Constitutional Court in $1997 .{ }^{34}$ Last year, the Columbian Senate finally approved regulations some 15 years after the practice was decriminalised. ${ }^{35}$

In contrast, the position of the leading common law jurisdictions - with whom we share a familial likeness - is more conservative. Indeed, it has been said that "for over 700 years, the Anglo-American common law tradition has punished or otherwise disapproved of both suicide and assisting suicide." ${ }^{\prime 36}$

\section{United States}

Euthanasia continues generally to be illegal in the US, although physician assisted suicide has been legalised in the states of Washington, Oregon and Montana. The American courts have heard several landmark cases related to assisted dying. The first major decision was that of the New Jersey Supreme Court in
Re Quinlan, ${ }^{37}$ which recognised that there is a constitutional right of personal privacy that encompasses a patient's decision to decline medical treatment. Even when Karen Ann Quinlan became incompetent, her right of privacy persisted. It was concluded that " $[\mathrm{t}]$ he only way to prevent destruction of the right is to permit the guardian and family of Karen to render their best judgment, subject to the qualifications hereinafter stated, as to whether she would exercise it in these circumstances." ${ }^{\prime 38}$ The Court therefore granted a declaration that life support may be withdrawn if there was no reasonable possibility of Karen emerging from her comatose condition and if the guardian and family of the patient considered that this would accord with how the patient would have acted.

The next case concerned Nancy Beth Cruzan, who was left in a PVS following an automobile accident. After being artificially sustained for several weeks, her family sought to end life-support but met with the resistance of Missouri hospital officials who insisted that court approval had to be obtained. The state court authorised the removal of Cruzan's feeding tube at first instance, but this was reversed by the Missouri Supreme Court. On appeal to the US Supreme Court, the Justices were unanimous on one point - that the Due Process Clause in the 14th Amendment to the US Constitution protected a competent person's right to refuse unwanted medical treatment. But there was a notable departure from the New Jersey Supreme Court in Re Quinlan. The Court in Cruzan emphasised the need for evidence regarding the patient's own intentions instead of accepting the surrogate judgment of the patient's guardians. The Court also held that the right to refuse treatment was not an unqualified right and had to be balanced against the state's power to impose conditions. As such, it was decided by a 5-4 margin that the State of Missouri's actions in preserving human life were constitutional in the absence of "clear and convincing evidence" that Cruzan desired treatment to be withdrawn. ${ }^{39}$ Cruzan's family eventually uncovered more proof of her intentions and won a court order to have her removed from life support.

Then there is Terri Schiavo, a 27-year-old woman who suffered a major cardiac arrest on 25 February 1990 but was then resuscitated, albeit that her brain had been deprived of oxygen for several minutes. As a result she suffered irreversible brain damage and was in a PVS. After eight years of unsuccessful efforts to improve her condition her husband sought the permission of

\footnotetext{
${ }^{31}$ Buffalo, NY: Prometheus Books, 1991 at 160 quoted in At liberty To Die, supa $n 5$ at $\mathrm{p} 70$

32 Jennifer M Scherer, Rita James Simon, Euthanasia and the Right to Die: A Comparative View (Rowman \& Littlefield Publishers, Inc., 1999) at p109

${ }^{33}$ Katsunori Kai, "Euthanasia and Death with Dignity in Japanese Law" Waseda Bulletin of Comparative Law Vol 27

${ }^{34}$ Corte constitutionnel de Colombia, Sentencia C-239/97, 20 May 1997; see also http://www.nrlc.org/news/2001/NRL06/rai.html (accessed 8 March 2013)

35 http://colombiareports.com/colombia-news/news/25483-colombian-senate-approves-regulation-of-euthanasia.html (accessed 8 March 2013)

${ }^{36}$ Washington $v$ Glucksberg 521 U.S. 702 at 704

${ }^{37} 70$ N.J. 10 (1976)

38 Ibid at 44

${ }^{39}$ Cruzan v. Director, Missouri Department of Health 497 U.S. 261 (1990)
} 
the court to remove her feeding tubes but this was opposed by Terri Schiavo's parents. This marked the beginning of a prolonged and extremely painful legal battle that involved the American courts, legislators and even the White House in what at bottom was a family dispute of the most personal and intense nature. I do not deal with the case in detail because it reveals more about the deep political, religious and moral differences that surround the issue and the very real prospect of such decisions becoming utterly politicised, rather than teaching us how the legal issues might be resolved. As it turned out the Supreme Court repeatedly declined to hear the case.

The next two cases which reached the US Supreme Court involved doctors in the states of Washington and New York challenging bans on physician assisted suicide. In Washington $v$ Glucksberg ${ }^{40}$ to which I have already referred and Vacco v Quill, ${ }^{41}$ the plaintiffs contended that the Fourteenth Amendment to the US Constitution protected a liberty interest for competent and terminally ill adults to commit suicide with the assistance of a physician. The Supreme Court was unanimous that no such liberty interest existed. Instead, it stressed that the distinction between assisting suicide and withdrawing life sustaining treatment was "both important and logical", and that the latter was not grounded on "a general and abstract 'right to hasten death'... but on well established, traditional rights to bodily integrity and freedom from unwanted touching." ${ }^{\prime 42}$

Taken in their totality, these cases show that the American courts have cleaved closely to the guiding principle of one's liberty to refuse unwanted medical treatment, and have thus far shown no signs of crossing to the other side of the act-omission divide.

\section{United Kingdom}

This leads us back to the UK, and to Debbie Purdy. In the UK suicide is not a criminal offence, though s 2(1) of the Suicide Act 1961 ("the UK Suicide Act"), provides that:

A person who aids, abets, counsels or procures the suicide of another, or an attempt by another to commit suicide, shall be liable on conviction on indictment to imprisonment for a term not exceeding 14 years.

Section 2(1) of the UK Suicide Act explains why there is no equivalent to Dignitas in the UK. Further, even though Debbie Purdy would break no law in travelling to Belgium or Switzerland to terminate her life, Omar Puente would be at risk of prosecution under s 2(1) of the UK Suicide Act were he to assist in making arrangements for her to travel abroad for that purpose. This left her in a quandary as she would almost certainly need her companion's assistance to make the necessary arrangements if she wished to commit suicide. Placing Omar Puente at risk of prosecution would therefore impede Debbie Purdy's ability to choose to end her life. The decision whether to prosecute someone who has rendered such assistance is exercised by the Director of Public Prosecutions (DPP) and the DPP had declined to promulgate any guidelines as to when he would or would not prosecute an offender, insisting that this was a matter for the exercise of prosecutorial discretion in each case.

In order to clarify the legal position for herself and for Omar, Debbie initiated civil proceedings seeking judicial review of the DPP's failure to promulgate a specific policy as to the circumstances in which a prosecution under s 2(1) of the UK Suicide Act would be brought.

An important case on assisted suicide had already been brought to the UK courts by a lady who was in much the same situation as Debbie Purdy. Mrs Diane Pretty suffered from motor neurone disease and she wanted to obtain legal immunity from prosecution for her husband. Her claim was eventually dismissed by the House of Lords, which held that the DPP had no power to override the laws that had been passed by Parliament. In the UK Suicide Act, Parliament had enacted legislation to proscribe the assistance of suicide. The DPP could not override Parliament by granting any person or class of persons immunity from the enforcement of such legislation.

Mrs Pretty then took her case to the European Court of Human Rights ("the European Court") in Strasbourg, arguing that her rights under Article 8 of the European Convention on Human Rights and Fundamental Freedoms ("the European Convention") were being infringed by the operation of the UK Suicide Act. Article 8 is headed as the "Right to respect for private and family life". It has two limbs. An applicant needs first to demonstrate that the subject matter of his claim falls within the ambit of Article $8(1)$, such that the right to private and family life is engaged; he must then show under Article 8(2), that the public authority's interference with the rights is wrongful or excessive.

The House of Lords had ruled that Mrs Pretty's Article 8 rights had not been engaged at all. ${ }^{43}$ The European Court took a different view. ${ }^{44}$ It observed that the ability to conduct one's life in the manner of one's choosing extended to the opportunity to pursue activities which are dangerous to oneself and ultimately

\footnotetext{
40 521 U.S. 702

41 526 U.S. 793

42 Ibid at pp 800-801, 806

${ }^{43} \mathrm{R}$ (Pretty) v Director of Public Prosecutions (Secretary of State for the Home Department intervening) [2002] 1 AC 800

${ }^{44}$ Pretty v UK [2002] ECHR 427
} 
even those that are self-destructive. The Court considered that the right to private life included or extended to the right to choose how to pass the closing moments of one's life, thus placing the premium on individual autonomy. The European Court also seemed not to accept the distinction between a refusal to accept medical treatment and a decision to take steps to accelerate death (see at [63] of the judgment). The European Court considered (at [65]) that under Article 8, the notion of quality of life was significant and went on to observe that:

In an era of growing medical sophistication combined with longer life expectancies, many people are concerned that they should not be forced to linger on in old age or in states of advanced physical or mental decrepitude which conflict with strongly held ideas of personal identity.

As the European Court found that Article 8(1) was implicated, it became necessary to consider whether the interference with this right by the provisions of the UK Suicide Act passed muster under Article 8(2). On this, the European Court found on the facts that the state's interference was compatible with Article $8(2)$, and that the proscription of assisted suicide was necessary and proportionate. But the decision of the European Court in Pretty $\vee$ UK did leave the door open for Debbie Purdy some half-dozen or so years later to argue that her Article 8(1) rights had been engaged, and to use that as a peg on which to hang her argument before the UK courts that she should be entitled to know the chances of Omar Puente being prosecuted if he assisted her on her final journey.

Both the Divisional Court and Court of Appeal dismissed Ms Purdy's claim in deference to the rule that the lower courts should follow the decision of the House of Lords. The main fight, therefore, occurred at the House of Lords, which was invited to depart from its position in the Pretty case. The leading judgment of the House was delivered by Lord Hope. Their Lordships had no difficulty in deciding that Article 8(1) was indeed engaged. As for Article 8(2), the House of Lords concluded that the circumstances surrounding assisted suicide were so unusual and sensitive that the DPP should state clearly what factors would be relevant to the public interest in such cases, and allowed Ms Purdy's appeal.

The decision in Purdy brings home the profound effect that European human rights jurisprudence has had on the law of the UK. The reversal in outcomes between Pretty and Purdy would likely not have occurred were it not for the influence of the European Court. In a sense, the European Court has begun to operate as a conduit through which civil law jurisprudence will increasingly influence the English common law.

Whether this will lead to better normative outcomes is open to debate, but perhaps the impetus that drives change on such profound ideological matters ought ideally to come from within the very own political community of those directly affected. Notably, after the Purdy decision a Bill was proposed to the UK Parliament to amend the law so as to conclusively remove the threat of prosecution from those who assist others to travel abroad to end their lives but this was rejected by a clear margin in the UK Parliament.

In September 2010 the Commission on Assisted Dying was set up to review the legal and policy approach to assisted dying in England and Wales. The Commission, chaired by Lord Falconer, undertook an exhaustive inquiry which included a public call for evidence from both experts and lay-persons, international research into jurisdictions where some form of assisted dying is permitted, and original research into the implications for the terminally ill and those who are in "vulnerable groups" such as the disabled and the infirm. The Commission concluded that the legal status of assisted suicide in the UK was "inadequate, incoherent and should not continue". Accordingly, it recommended the introduction of an assisted dying framework for mentally sound patients above the age of 18 who are suffering from a terminal illness which leaves them with less than 12 months to live. The suggested framework was hedged with safeguards such as requiring the approval of two independent doctors, a mandatory time period between the request for the procedure and its execution, and the creation of a national monitoring commission to provide regulatory oversight.

Despite these efforts, the Commission's Report has met with a mixed reception. The UK Government has publicly indicated that this should be a matter for Parliament to decide and that there were no plans to change the law. Significantly, the UK Parliament has, in the last decade rejected three attempts to change the law on assisted dying.

\section{The position in Singapore}

Against all that, we turn now to the position of the law in Singapore which is, in broad terms, probably most comparable with the state of the law in the US.

Attempted suicide is an offence in Singapore by virtue of s 309 of the Penal Code. Read together with s 107 of the Code, any abetting of an attempted suicide is also a crime. Where the attempt to commit suicide succeeds, s 306 of the Penal Code provides that the abettor of the suicide shall be punished with imprisonment for a term of up to ten years, and shall also be liable to a fine. The law is therefore clear and unequivocal. Physicians who assist their patients in committing suicide will be committing a crime, given s 306 and s 309 read with s 107 .

The foregoing may well also be the case for friends and family members who assist their loved ones to travel abroad for physician assisted suicide though there may be some difficult issues as to which I express no concluded views beyond 
observing that if an attempted suicide takes place abroad, the presumption against extraterritorial application may be such that it may not fall within the jurisdiction of our courts; though it may perhaps be argued that s 108A operates to render the abetment of the attempted suicide a crime where the acts of incitement or assistance occur within Singapore.

Our position in relation to end-of-life issues is regulated to some degree by the Mental Capacity Act (Cap 177A, 2010 Rev Ed). Section 3(5) stipulates that an act done, or decision made for or on behalf of a person who lacks capacity must be done, or made, in his best interests. Relevant decision makers include caregivers, nurses, doctors or court-appointed deputies. What, then, would constitute a person's 'best interests'? We can take guidance from the non-exhaustive list of significant factors set out in s 6 of the Act. Section 6(5) states that where the decision relates to whether life-sustaining treatment is in the best interests of the patient, the decision-maker must not be motivated by a desire to bring about the patient's death. In addition, s 6 takes an expansive, indeed all-inclusive, approach which covers both prospective assessments of future welfare (s 6(3)) and retrospective inferences of what the patient would have intended (s 6(7)). This will of course be challenging to apply in practice, but it sends a strong signal of the need to be comprehensive and to strike a balance between the full range of considerations when acting as a substitute decision-maker.

Finally, the AMD Act provides a system for competent adults to refuse life-sustaining medical treatment. The AMD remains the most reliable means of ascertaining the patient's wishes. It becomes relevant if the patient is terminally ill (i.e. is suffering from an incurable condition from which there is no reasonable prospect of either temporary or permanent recovery and death, as a matter of reasonable medical judgment, is imminent). Under s 9, the question of whether the patient is terminally ill must be answered unanimously by the patient's doctor and two other doctors (and at least two of the three must be specialists empanelled for the purpose of such assessments). If either of the two referred doctors disagree, the matter must be referred to a committee of three specialists and the determination that the patient is terminally ill may only be made by the committee unanimously.

The AMD is a directive made by an adult who is not mentally disordered and who desires not to be subjected to "extraordinary life-sustaining treatment". This in turn is defined as treatment that will only prolong the process of dying but excludes palliative care. As a matter of practical use, an AMD will not be retrieved until the patient has lost the capacity to decide, and so it is and remains a confidential document until nearly the end. Even at that point, however, the physician cannot be absolutely certain that the AMD has not been revoked, as revocations can be made orally and need not be registered. As such, it is clear that the AMD system was never intended to operate in a way which would allow caregivers and physicians to abdicate their responsibilities toward an incompetent patient. Nevertheless, it remains a worthwhile instrument which encourages competent adults to engage in a serious discourse on end-of-life issues and to treat death as a fact of life. Physicians therefore have a crucial role to play in advising their patients to consider these issues and to continually update the legal instruments which may be used as proxies of their intentions.

Significantly, the Act in s 17 explicitly states that nothing in it authorises any act that causes or accelerates death as distinct from that which permits the dying process to take its natural course. The Act also states that nothing in it condones, authorises or approves the abetment of suicide, mercy killing or euthanasia.

The AMD Act is a carefully structured statute that sticks close to the common law distinction between acts and omissions, by enabling recognition to be accorded to a patient's expressed preference not to continue to receive treatment. But this is made subject to a number of important safeguards that are directed principally at avoiding these important decisions being made by those in any conflict of interest and at ensuring that there is as much certainty as possible on contentious medical issues.

\section{CONCLUDING THOUGHTS}

In the final analysis, we might not be able to reach any categorical conclusions on accelerated and assisted dying beyond saying that these are profound issues over which there is scope for deep differences in views. It would be presumptuous and certainly unfeasible for me to give answers today to the resolution of these issues. But there is value in drawing out some broad points that could inform further discussion about these issues:

a. The common law has long drawn a distinction between the right to refuse treatment which is recognised within the ambit of a right to bodily integrity on the one hand, and the ability to choose the moment and means of one's passing by actively taking steps to end life. Does this remain a valid distinction?

b. If it is thought that the distinction is not valid, then is there any logical stopping point which restricts the circumstances in which and the persons by or in respect of whom steps may be taken to terminate life? Should there be any restriction on one's personal autonomy over decisions to end life? Is it ultimately humane to say that only those who are disabled or depressed or over the age of 70 may opt for this? What do such choices say about how the rest of society views these groups, who as Baroness Campbell says, most need the support of the rest? Will it fundamentally alter the role of doctors or affect the nature of the doctor-patient relationship if active steps to terminate life or to hasten death were regarded as medical treatment options? 
c. When personal autonomy is not in play because the patient is unable to express a preference and/or to act on it, who decides? And on what basis?

d. To what extent can or should the experience of other countries in legalising assisted suicide or voluntary euthanasia be relevant to our own choices given that abstract notions about human rights may cease to be universally applicable when they are concretised?

e. To what extent should the limits of our knowledge about science constrain the decisions we might make that are irreversible in nature? Or should the preference be for conservatism given what we don't know about what we don't know?

f. How slippery and steep might be the slope that starts with a narrow exception permitting assisted suicide in limited circumstances?

The experience of common law courts abroad suggests that perhaps, the choices about these matters are best not left to the courts. It is useful here to refer to Justice Scalia's observations in Cruzan v Director, Missouri Department of Health ${ }^{45}$ at 282:
The various opinions in this case portray quite clearly the difficult, indeed agonizing, questions that are presented by the constantly increasing power of science to keep the human body alive for longer than any reasonable person would want to inhabit it ... [The answers] are neither set forth in the Constitution nor known to the nine Justices of this Court any better than they are known to nine people picked at random from the Kansas City telephone directory.

Precisely because these are deeply dividing, even ideological differences, it must be for Parliament to legislate any changes, such as has happened with the AMD Act. The challenge for the courts will be to deal with particular issues as they arise from time to time. As is the wont of the common law, any development will have to be incremental and founded upon well-established principles. In the meantime, this should continue to be a matter for public debate, private conversations with our loved ones, and personal reflection. If you intend to embark on such debate, conversations and reflection, I hope my lecture will have given you some material to inform the process.

${ }^{45}$ See supra $n 39$

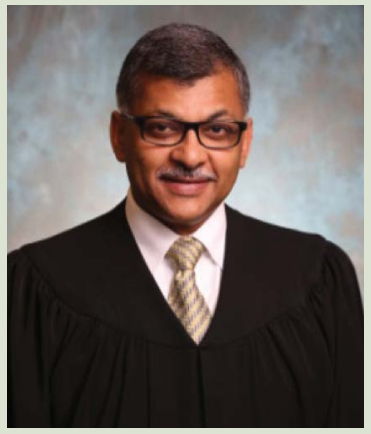

\section{About the Lecturer}

Mr Menon graduated with a Bachelor of Laws (First Class Honours) from the National University of Singapore in 1986, and later obtained a Master of Laws degree from Harvard Law School in 1991. He was admitted as an advocate and solicitor of the Supreme Court of Singapore in 1987, and as an Attorney and Counsellor-at-law of the Bar of the State of New York in 1992. He was appointed Senior Counsel in January 2008.

As a private practitioner, Mr Menon was recognised as one of the leading lawyers in the fields of commercial litigation and arbitration, insolvency and construction law, in Singapore and abroad. He advised and represented numerous local and overseas clients in complex and technical disputes, and appeared in arbitration tribunals in various jurisdictions. Mr Menon has also served as the Deputy Chairman of the Singapore International Arbitration Centre and represented Singapore at the UNCITRAL Working Group on Arbitration.

From April 2006 to March 2007, Mr Menon served as a Judicial Commissioner of the Supreme Court, and presided over several prominent criminal and civil cases in the High Court. After completing his term on the Bench, he returned to Rajah \& Tann as a Managing Partner in August 2009, a position he held until his appointment as the Attorney-General of Singapore on 1 October 2010. Mr Menon relinquished his position as Attorney-General on 24 June 2012 and was appointed a Judge of Appeal of the Supreme Court on 1 August 2012. On 6 November 2012, Mr Menon was appointed the Chief Justice of Singapore.

The 2012 SMA Lecture was delivered on 9 March 2013 at the Grand Copthorne Waterfront Hotel. The citation of Mr Sundaresh Menon was delivered by Dr Chong Yeh Woei, 1st Vice President of the 53rd SMA Council. A copy of the citation is published in the March 2013 issue of the SMA News. 